\title{
Privatisation and the Government Cost of Capital
}

\author{
Neville Hathaway
}

I F the cost of capital is lower for government for than for the private sector, then instead of privatising their assets governments should buy all the shares listed on the public stock exchanges. They should also undertake to invest in many of the risky new ventures that the private sector considers too marginal for investment.

If the government cost of capital were the government bond rate, then government ownership would raise the aggregate market value of all the listed stocks on the Australian Stock Exchange from the current figure of about $\$ 400$ billion to about $\$ 800$ billion. The private sector requires about 14 per cent a year for equity investments but the government ten-year bond rate is only about 7.5 per cent a year. If we ignore, for the moment, the question of company tax payments, the same cash flow under government ownership as under private ownership would be discounted at 7.5 per cent a year rather than the private sector's 14 per cent, thus approximately doubling the value of all equities. We would be better off if we bought government debt and governments, in turn, invested in equities (indeed, all assets) on our behalf.

If the government cost of capital were lower than the private sector cost, then government could accept investment proposals that the private sector rejected as uneconomic because they have a negative net present value (NPV): that is, the present value of future benefits arising from an investment proposal is less than the capital investment. An investment with an NPV that was negative for the private sector could very well become positive under government ownership. Projects that the private sector rejected as too risky could be pursued by the government on behalf of the public. If the government cost of capital was just the government bond rate, then the cost of capital for any government project would be independent of the risk embodied in that project.

These unacceptable conclusions should serve to indicate that the argument that the cost of capital is lower for government than for the private sector is fallacious. This argument has two strands: that the government sector need not pay company tax, and that the government sector can borrow at lower rates than the private sector. But although both of these observations are correct, it does not follow that the government cost of capital is lower than the private sector cost. 
The argument has been used to oppose the privatisation of government business enterprises (GBEs) and to give the impression that the public has lost value from past privatisations and will lose from future privatisations such as the proposed sale of Telstra (in part or in whole). For example, John Quiggin states that

... the discount rate used by stock markets in evaluating the expected flow of returns from a privatised GBE may be much higher than the government's opportunity cost of funds. Hence, other things being equal, a policy of selling profitable assets and using the proceeds to pay off debt will reduce public sector net worth (Walker, 1994) ... (Quiggin, 1995:25)

Such arguments violate the basic logic of the valuation and cost of capital. If any investor, public or private, sells shares to the value of $\$ 100$ and deposits $\$ 100$ in the bank (or, equivalently, reduces his bank debt by $\$ 100$ ), he has not destroyed wealth but just reallocated it from higher-risk shares to lower-risk debt. Certainly there will be different annual cash flows (returns) arising from this change in asset allocation; but this merely reflects the different risks involved. The case for privatising GBEs does not turn on the cost of capital for GBEs.

The GBE cost of capital must be the same as the private sector's pre-tax cost of capital. There is, therefore, no 'valuation wedge' between private and public ownership, given the same operating efficiencies of the enterprise, notwithstanding the corporate 'taxation wedge' between private and public ownership. This finding has important implications for the case for privatising GBEs.

\section{Basic Principles}

Any analysis of the cost of capital applicable to government assets, particularly GBEs, needs to recognise the following points:

- Since government equity in GBEs is traded only when the asset is sold, the risk in government equity holdings cannot be observed.

- The market return for risk (that is, the price of risk) represents the appropriate charge for risk to be added to the GBE discount rate, particularly, but not solely, for the equity holding.

- Since GBEs do not pay company tax (notwithstanding the practice of their owners charging GBEs 'tax equivalents'), the cash flow to government owners will be different from that to private-sector owners. The introduction of imputation tax credits has reduced this difference.

- The market rate for government debt is not directly applicable to a GBE investment appraisal because the government rate reflects its profound ability to service debt through its power to raise taxes. 
- The low government cost of debt represents the guaranteed service cost of debt, whereas investment appraisal and GBE valuation must reflect the cost of application of the funds.

- Selling (privatising) a GBE and retiring debt does not destroy value but restructures the debt-equity mix that a government holds in its portfolio of assets.

Taken together, these points simply confirm that it is the nature of the asset, and more particularly the net cash flow, that determines the required return (the cost of capital).

Each of the points is explored in detail below. The cost of debt and the cost of equity are explored first separately and then jointly in the implications for the financial structure (the relative proportions of debt and equity).

\section{The Unobservable Cost of Government Equity}

The routine non-tradability of government equity forces analysts to use discounted cash flow (DCF) to value GBEs. Governments rarely inject equity into GBEs. ${ }^{2}$ But although the equity component of the business is invisible unless and until it is privatised, it should not be ignored. For instance, before being restructured, Melbourne Water was valued at between approximately $\$ 6$ billion and $\$ 8$ billion, with debt outstanding of between approximately $\$ 3$ billion and $\$ 4$ billion. ${ }^{3}$ Clearly, there was substantial book equity involved in Melbourne Water, stemming from retained earnings and the proprietary claim over the cash flows of the metropolitan water business that government conferred on Melbourne Water. Further examples are the large equity components of Victoria's electricity distribution and generation businesses.

Some GBEs are financed almost wholly with debt, which capital markets are prepared to provide precisely because government is empowered to raise future capital through taxation in order to repay the debt. Such excessive debt financing represents future tax collections and there are good reasons, in terms of reduced agency costs; to 'load up' GBEs with debt. So, in valuing a GBE or appraising a GBE's investments, allowance must still be made for the cost of equity implicit in the enterprise.

If the GBE equity or that of a comparable company was traded on the open market, its value, and hence its cost of capital, would be visible. The absence of comparable companies with traded equity creates significant validation problems. For example, the privatised GBE may undergo extensive restructuring, be operating in a different regulatory environment, and possibly have to undertake large capital

\footnotetext{
In valuing an enterprise, whether state-owned or privately-owned, the weighted average cost of debt and equity capital (WACC) is typically used to value the free cash flows. The weights in the WACC are the proportions of the enterprise value reflected in equity and debt respectively.

2 3

Private commissioned report.
} 
projects, particularly infrastructure investment. The monopoly power that GBEs frequently enjoy enables them to share the risk inherent in such projects with the customers by way of cost-plus or take-or-pay contracts. And the privatised GBE's prospective level of earnings and growth may be quite different from its historical results. These difficulties usually force us to conduct valuation from first principles, in the form of DCF analysis, for which the cost of capital (the discount rate) is needed. Assessments of the government cost of capital must make allowance for the (hidden) cost of equity and the subsidised cost of debt.

\section{GBE Equity Risk}

Whereas private sector investors choose to bear the risk involved, taxpayers involuntarily bear the risks of government equity in GBEs. GBE investments must therefore include an allowance for risk that these investors would require had they invested voluntarily. As a voluntary investment would generate a market return for risk, the appropriate allowance for GBE risk is the market price of risk. For example, competition from Victoria's privately owned electricity generators is adding to the risk that is borne by New South Wales taxpayers, the involuntary investors in their State's generators.

If held under government ownership, the risk in a GBE investment cannot be totally diversified. Using this logic, Bailey and Jensen (1972) have demolished arguments for a zero-risk premium (that is, for using risk-free rates) in GBE investment. When assets are held in widely diversified portfolios, that part of the risk unique to that asset is eliminated (diversified away) leaving only the risk in common with the rest of the portfolio (the systematic risk). Regardless of who holds the assets, a widely diversified portfolio risk will always exist, since systematic risk is an attribute of the asset, not of the owner of the asset. In addition, since government income and the cash flows (such as electricity sales) from significant GBE investment will vary with the state of the economy, it is extremely unlikely that government ownership of GBEs will permit further diversification of risk than is already achieved in the portfolios widely held by households. The non-government sector holds an extremely widely diversified portfolio of assets, to such an extent that any additional assets held by the non-government sector provides no further diversification benefit. The argument that governments have access to opportunities for risk diversification that are unavailable to private investors suggests that there is some impediment in risk diversification in the private sector. But there is no logical reason why this should be the case, nor is there any evidence that it is.

It has been claimed (for example, Mehra \& Prescott, 1985) that the observed return on risky equity investments includes a risk premium (a return in excess of the risk-free rate) that is higher than would be warranted by the risk inherent in these investments. This is known as the 'equity premium puzzle'. It arises from comparing the observed market risk premium with that predicted by models that attempt to describe the tradeoff between current consumption and future consumption (that is to say, that attempt to model the required discount rate and hence the required risk premium). But which should we believe: the evidence of the observed risk pre- 
mium from capital markets, or a model based on a theory that claims the risk premiums are too high? The 'puzzle' does not invalidate the observed market risk premium; rather, the observed market risk premium proves that the model is flawed.

\section{GBEs and Company Tax}

The fact that GBEs do not pay company tax (notwithstanding their owners charging GBEs 'tax equivalents') is the most widely cited basis for the argument that the government cost of capital is less than the private sector cost.

The concept of the 'social opportunity cost of capital' is sometimes invoked to specify the return governments require when making investments on behalf of the community. It is the rate at which society is willing to forgo present consumption for the sake of future consumption. With this discount rate, the discounted value of future consumption goods equals the value of forgone present consumption goods. It is thus a consumption-based opportunity cost of capital (COC).

For government investment replaceable by private investment, the appropriate discount rate is the private sector's pre-tax investment opportunity cost (IOC). Private sector investment to supply future consumption goods would incur taxation. In order to meet expected future consumption needs, private investments would therefore need to yield an allowance for taxation. In this case, the private sector would willingly invest to supply the future good if it made its market rate of return reflect all its costs. Society would be supplied with both a future good and a taxation payment. Hence, if the government replaces private sector investment with a GBE, its opportunity cost is the cost of the good and the forgone taxation payment. As long as government does not waste tax revenue, the appropriate discount rate for GBEs is the private sector pre-tax cost of capital. This is no more than a recognition that the appropriate discount rate is an opportunity cost: in this case, the government's opportunity cost of capital.

As a government investment in a GBE does not incur company tax, its cash flow and its required return should be calculated on a pre-company tax basis. The observed cost of capital for the private sector, in contrast, is the cost of capital after company tax but before personal tax, since the vast majority of debt and equity securities traded in the market render investors liable for personal tax but not for further company tax. This does not pose a problem because the GBE valuation can equally be performed on a post-tax basis, as is commonly done for private enterprises, since pre-tax cash flows discounted at pre-tax discount rates and post-tax cash flows discounted at post-tax discount rates should give consistent valuations. The important point is that there is no valuation wedge caused by the taxation wedge between private and government ownership.

Since the value of an asset does not depend on the tax status of its owner, it must be the same for both the private sector and the public sector. For the same

\footnotetext{
This section draws heavily on Baumol et al. (1983).

${ }^{5}$ Namely, IOC $\left(1-T_{c}\right)=\operatorname{COC}$ or IOC $-\mathrm{COC} /(1-\mathrm{Tc})$ where $\mathrm{Tc}$ is the effective tax rate.
} 
operational efficiency, the pre-tax cash flow is the same for both forms of ownership. The government sector's cost of capital for a GBE is the private sector's pretax cost of capital.

Dividend imputation has obscured this somewhat. In the private sector, the pre-tax cost of capital depends on the amount of corporate tax that the company pays. This is the amount of the tax collected at the company level that is not claimed (redeemed) by shareholders as pre-payment of their personal tax. The redeemed amount of the collection flows to shareholders as an addition to their prepersonal tax cash flow. If all the tax collected at the company level were distributed as franking credits and the shareholders could fully utilise them, then, strictly speaking, no company tax would actually be paid. In other words, the pre-tax cost of capital would be the same as the post-tax cost. In Australia, where foreign shareholders do not pay Australian personal tax, an average of about 45 per cent of the tax collected from companies is redeemed as franking credits on personal tax (Hathaway \& Officer, 1996). This reduces the private sector's pre-tax cost of capital but not to the level of its post-tax cost.

The cost of capital to government is the private sector's pre-tax cost taking into account the reduction in company tax caused by the imputation credit system. Tax equivalent payments, which under government ownership take the form of cash, under private ownership become franking credits, whose market value depends on the pay-out policy of the firm concerned and its ability to distribute franking credits. Since retained earnings are available for reinvestment by the company, they should earn their opportunity cost of capital, so compensating investors for the time value of money caused by not distributing the earnings as dividends. However, franking credits remain with the Australian Taxation Office until redeemed at their face value by personal taxpayers. As there is no compensation for the time value of money, they are a 'wasting' asset while they remain undistributed. The market value of companies with stored credits will embody any discount that investors consider appropriate.

The upshot is that the cost of capital to government will depend on the market value of the imputation credits generated by the particular GBE. This adds one more parameter that must be estimated in order to establish the GBE cost of capital. Nevertheless, the government as the owner of a GBE receives a pre-tax cash flow for the same market pre-tax cost of capital as the private sector.

\section{Government's Borrowing Advantage}

The government's borrowing advantage reflects its ability to service debt by its power to tax. Its borrowing rate is low because it reflects this very strong guarantee to repay. Indeed, governments can finance consumption expenditure with debt which has no future cash flow to meet the debt obligation. Lenders know that the power of taxation stands behind the debt obligation. Only if there were a risk of default on this obligation would the debt rate be affected. The risk of the investment to which the debt is applied is not reflected in the cost of servicing the debt. 
But its borrowing rate is not the opportunity cost of debt that should be used in appraising GBE investments. If a private borrower could supply the same security of repayment, it too would be able to secure debt at a lower cost.

\section{Servicing Cost vs Investment Cost of Debt}

The appropriate measure of the cost of capital for investment valuation is the cost of the application of the capital in the investment, not its cost at source. For example, if one borrowed long-maturity debt in order to purchase equities, then the required return on the capital would be the investment return on equities (say, 14 per cent a year), not the cost of servicing the debt (say, 7.5 per cent a year). Clearly, the difference in the costs reflects their different risks. When government raises debt capital, the service cost of debt is the repayment rate, as guaranteed by taxpayers. Without the guarantee, the cost of the debt would reflect the risk to the lenders in making the loan. This is the cost of debt that should be used in investment appraisals.

There is no reason to subsidise a GBE and its clients with the guarantee which taxpayers supply. In theory, this guarantee could be applied to any investment, private or public. But it does nothing to enhance the efficiency of the investment. It is all external diseconomy in production: it costs society more than it costs the GBE. State Treasuries now acknowledge this and charge a guarantee levy to their GBEs, though it remains unclear whether it is sufficient to wholly eliminate the diseconomy.

\section{Debt Retirement and Net Worth}

An investor who sells higher-risk equity to reinvest in lower-risk debt securities (or, equivalently, to reduce his sale of debt securities by repurchases) does not thereby make himself worse off, because the higher equity cash flows compensated him for bearing the higher equity risk. The risk in the equity cash flow from Telstra, for example, is surely greater than the risk-free rate of interest due on government debt. Selling $\$ 100$ of equity in Telstra and investing in $\$ 100$ of debt securities (or retiring $\$ 100$ of debt) does not destroy wealth, apart from any transaction costs incurred. To claim that taxpayers are made worse off by privatisation is essentially to claim that the mix of debt and equity is wrong. This is to assume that there is an optimal mix of debt and equity for the government. Yet there is no compelling evidence that any such optimal capital structure exists.

The arguments about the debt-equity mix apply equally to the private sector and the public sector. According to Jensen (1986), large, mature listed companies generate substantial 'free cash flow' which cannot be profitably reinvested within the company. Managers are inclined to employ such cash flow to underwrite growth at the expense of profitability: for example, they may attempt to gain market share in a mature industry or purchase diversification investments which add no shareholder value. But a high level of debt takes away this freedom to be profligate with shareholder's cash by placing contractual obligations on the company. 
Because managers of GBEs are even more remote from their ultimate shareholders (the public), Jensen's free cash flow argument is more compelling for GBEs than for private companies, which may help explain why GBEs are more loaded with debt than are private corporations. For example, free cash flow may be wasted on excessive allowance for contingencies or excessive investment in reserve equipment (such as standby electricity generation equipment instead of more power outing compensation contracts with large consumers). But higher debt levels than would otherwise be the case could counter any tendency for such profligate behaviour and for political interference in GBE operations. This is because high debt levels remove much of the managers' discretion to accede to such demands and pressures. Yet, notwithstanding these possible differences between private and government ownership, no obvious conclusion can be drawn about the optimal mix of debt and equity for government investment.

Owning GBEs, which are essentially domestic businesses, 'doubles up' the government's exposure to the Australian economy. As economic conditions fluctuate, so do the general tax collections of government and the earnings of GBEs. As the owner of GBEs that are financed with long-term debt, the government has levered itself to the Australian economy. Prudent investors might regard this degree of leverage as unwise and judge that a lower level, such as privatisation would achieve, would improve their welfare.

\section{Privatisation}

The arguments about privatisation turn on considerations of efficiency rather than the cost of capital. An exclusive focus on valuation effects and debt retirement would lead the sellers (governments) to maximise their net benefit upon sale by privatising monopolies, at the expense of consumers. There is little or no public benefit in transferring a monopoly from public ownership to private ownership, unless it is accompanied by some efficiency gains.

The investment decision to create an asset and deliver a service should not be affected by the issue of the ownership of that asset. If the private sector can deliver a service, to the extent demanded by the community, more efficiently than the government sector, then that is the more valuable form of ownership. Capital released from inefficient businesses can be relocated to generate wealth elsewhere, so increasing national wealth. The resources used in generating a service should be the same under all forms of ownership. If they are not, then control of assets should pass to those individuals who judge they can manage them better and who are prepared to back their judgment by paying a greater capitalised value for an asset.

Privatisation lowers the agency cost of ensuring that managers act in the interest of shareholders. The publicly listed corporate structure has evolved to a form that suits the needs of all of its stakeholders: clients, managers and employees, owners and lenders. Managers are charged by the owners to act as their agents in promoting the interests of the business. Public listing imposes a discipline on the company. The enterprise will have to pay market rates for its inputs, whether physical or human capital; and this will be visible in the marketplace. A publicly listed company 
that is poorly managed will be punished in the marketplace. However, in government businesses, the returns that would otherwise accrue to private sector shareholders may be partially captured by others, such as employees and favoured customers, at the expense of the ultimate shareholders, the public.

The market-based system is largely self-regulating and it has little need for a bureaucracy to impose a negotiated allocation of resources between the managers of GBEs and their political masters. Corporatisation has been adopted to overcome this problem, but it cannot fully eliminate it. The market assumes the role of monitoring the performance of a privatised company. The well-being of the enterprise is succinctly embodied in one simple statistic: the stock price. The alternative is to impose a whole series of performance measures based on both input and output metrics for the enterprise. But the interpretation of such a series of statistics is bound to be more subjective than the market price of the stock, which is a simple and cheap form of information about managerial performance (among other things) and provides a powerful means, through the possibility of takeover bids, of disciplining poor performance.

Privatisation is often accompanied by reforms that enhance market competition and so ensure that consumers benefit from the reduced costs of production. Even when public monopolies are transferred intact to private ownership, they are often subjected to regulations that render management of the enterprise more open to scrutiny. Ideally, this should also help reduce the agency costs of making management act in the best interests of the enterprise.

If the GBE has community service obligations (CSOs) and they are deemed necessary, they can be handled just as easily (though more visibly) by private owners as under government ownership. They should not be obscured by being embedded in a lower required return on the asset when under government ownership. Any CSO should be explicitly identified, either as a subtraction from commercially priced cash flows or as a quarantined portion of the assets. As there are often joint costs involved in supplying commercial as well as subsidised services, it is difficult to quarantine the asset base used to service the CSO. The optimal solution is to subsidise the appropriate user of the service and require all investment decisions to be made on a commercial basis. Embedding CSOs in a lower required return creates the risk that the GBE will capitalise a prospective business at too low a rate of return by over-investing in assets or charging too little for its output: both of which represent a sub-optimal allocation of scarce national resources. Unfortunately, it is often easier politically to disguise CSOs as opportunity costs through reduced GBE dividends than to identify them explicitly as budgeted outlays by the government in combination with commercial dividend receipts from the GBE. Privatisation need not affect the issue of CSOs at all; but it does make CSOs more visible and forces politicians explicitly to allocate capital to them.

\section{Conclusion}

The cost of capital for GBEs is the opportunity cost of the capital, both debt and equity; and the cost of the equity is the appropriate before-tax risk-adjusted return 
on the business. Government equity invested in GBEs carries an opportunity cost, since the government can always use the capital for other purposes. The nontradability of GBEs' equity makes it difficult to estimate the equity risk premium; but this measurement problem does not validate the claim that the cost of capital is no more than the cost of debt.

The cost of capital for government is not less than it is for the private sector: it is the private sector's pre-tax cost of capital. The corporate tax wedge between private and public ownership of assets does not place a valuation wedge between private and public ownership; nor does the low rate of debt at which governments can borrow, because that is not the cost of debt that is relevant to an investment appraisal. Dividend imputation has somewhat obscured the difference between government and private sector costs of capital by lowering the effective company tax rate; but that is only a measurement problem. The basic principle still applies: given the same operating efficiency, there is no valuation gap between public and private ownership of assets, and no automatic loss of net worth when governments privatise their GBEs and retire debt with the proceeds of the sale.

The argument that privatisation should not proceed on the grounds that the capital costs government less than the private sector is therefore unsound. The case for privatising GBEs is based entirely on the efficiency gains it makes possible.

\section{References}

Bailey, M. \& M. Jensen (1972), 'Risk and the Discount Rate for Public Investment', in M. Jensen (ed.), Studies in the Theory of Capital Markets, Praeger, New York.

Baumol, W., S. Littlechild, J. Pincus, R. Officer, M. Porter \& C. Trengove (1983), State Enterprise and Denegulation, Centre of Policy Studies, Melbourne (Monash University Special Study No. 5).

Hathaway, N. \& R. Officer (1996), 'Valuation of Imputation Tax Credits', unpublished manuscript.

Jensen, M. (1986), 'Agency Cost of Free Cash Flow, Corporate Finance, and Takeovers', American Economic Review 76(2): 323-9.

Mehra, R. \& E. Prescott (1985), 'The Equity Premium: A Puzzle', Journal of Monetary Economics 15(2): $145-61$.

Quiggin, J. (1995), 'Does Privatisation Pay?', Australian Economic Review 2nd Quarter: 23-42.

Trace, K. (1995), “'You Couldn't Give It Away": Privatising the Australian National Line', Agenda 2(4): $433-44$.

Walker, R. (1994), 'Privatisation: A Reassessment', working paper, University of New South Wales, Sydney.

The author is indebted to Professor R. R. Officer and to participants at various seminars for comments on an earlier draft. The significant contributions of anonymous referees are also gratefully acknowledged. 